\section{Solution to the}

phylogenetic enigma of

\section{Tetraplatia, a worm-shaped cnidarian}

\author{
Allen G. Collins ${ }^{1, *}$, Bastian Bentlage ${ }^{2}$, \\ George I. Matsumoto ${ }^{3}$, Steven H. D. Haddock ${ }^{3}$, \\ Karen J. Osborn ${ }^{3}$ and Bernd Schierwater ${ }^{4}$ \\ ${ }^{1}$ NMFS, National Systematics Laboratory, National Museum of \\ Natural History, MRC-153, Smithsonian Institution, PO Box 37012, \\ Washington, DC 20013-7012, USA \\ ${ }^{2}$ Centre for Biodiversity and Ecology, Goldschmidtstrasse 3, \\ University of Göttingen, 37077 Göttingen, Germany \\ ${ }^{3}$ Monterey Bay Aquarium Research Institute, 7700 Sandholdt Road, \\ Moss Landing, CA 95039, USA \\ ${ }^{4}$ ITZ, Ecology \& Evolution, TiHo Hannover, Bünteweg $17 d$, \\ D-30559 Hannover, Germany \\ *Author for correspondence (collinsa@si.edu).
}

Tetraplatia is a genus containing two species of pelagic cnidarians of curious morphology. Their vermiform shape and four swimming flaps are difficult to relate to the features of other cnidarians, thus obscuring their phylogenetic affinities. Since their discovery in the mid-1800s, a number of prominent cnidarian workers have weighed in on this conundrum, some arguing that they are aberrant hydrozoans and others concluding that they are unusual scyphozoans. Current taxonomic practice conforms to the latter view. However, data presented here from the large and small subunits of the nuclear ribosome leave little doubt that Tetraplatia is in fact a hydrozoan genus. Indeed, its precise phylogenetic position is within Narcomedusae, as some authors had previously deduced based on structural characters. The distinctive body plan of Tetraplatia is remarkable because it appears to have a recent origin, in contrast to the prevailing pattern of metazoan history.

Keywords: Scyphozoa; Coronatae; Hydrozoa; Narcomedusae; ribosomal DNA; bodyplan evolution

\section{INTRODUCTION}

Among the many animals living in the open sea, a few present features that appear unusual even to the people who study them. Tetraplatia, with its vermiform body encircled by a set of four complicated swimming flaps, is one such animal (figure 1). Because it possesses nematocysts and fourfold symmetry, it is relatively easy to identify as a medusozoan (non-anthozoan) cnidarian. However, after that determination, no agreement about its phylogenetic position within this diverse group has been achieved. Tetraplatia has been identified as: (1) a close ally of cubozoans and staurozoans (Komai 1939); (2) a scyphozoan (Krohn 1865; Delage \& Herouard 1901; Carlgren 1909; Krumbach 1925; Ralph 1960; Russell 1970); and (3) a hydrozoan, but ascribed to very different hydrozoan groups, Narcomedusae and Anthoathecata (Claus 1878; Viguier 1890; Dantan
1925; Haeckel 1879; Hand 1955; Leuckart 1866; Weill 1934). Regardless of hypotheses about its phylogenetic affinities, past workers have always placed Tetraplatia in its own higher-level taxon, usually order, in recognition of its unusual form. Forty-five years have passed since the last scholarly treatment of the systematic position of Tetraplatia (Ralph 1960), which concluded that it is a coronate scyphomedusan. Current taxonomic practice, e.g. the Integrated Taxonomic Information System and the European Register of Marine Species, generally, reflects this hypothesis.

The genus Tetraplatia contains two species, T. volitans and T. chuni. The latter species appears to be particularly rare with just a handful of individuals, all from the South Atlantic, ever being recorded (Rees \& White 1957). T. volitans has been encountered much more frequently, occasionally in large numbers (Hand 1955; Ralph 1959), and is broadly distributed throughout the world's oceans (Hand 1955). It too, however, may be judged as relatively uncommon (or unnoticed) based on a paucity of recorded observations over the past several decades. Individuals of both species are small, generally ranging in length from one to ten millimetres. The two species differ in body proportions (Rees \& White 1957), and the presence or absence of yet another unusual feature, a set of four flying buttresses. In both species, the oral and aboral portions of the body are separated by a groove that encircles the animal and from which the four muscular, locomotory flaps arise. Between the flaps, in $T$. volitans only, hollow flying buttresses arch over the groove connecting the aboral and oral portions of the body (figure 1).

Despite its highly unusual form, a modest number of features have been used to argue for or against various phylogenetic hypotheses for Tetraplatia. Past workers have agreed that its cnidome consists of just a single type of nematocyst, atrichous isorhizas, in two size classes; its mesoglea is acellular; and its eight enclosed statocysts, two associated with each flap, are of endodermal origin. In contrast, they disagree about whether Tetraplatia possesses gastric filaments, a velum, or gonads of gastrodermal or epidermal origin. These discordant interpretations of histological preparations have been key elements of competing arguments about the phylogenetic affinities of Tetraplatia. We have attempted to resolve this phylogenetic question by sequencing genes coding for the large and small subunits of the nuclear ribosome (LSU or $28 \mathrm{~S}$ and SSU or $18 \mathrm{~S}$, respectively) and analysing sequences from Tetraplatia along with those from a diverse set of other cnidarians.

\section{MATERIAL AND METHODS}

A sample of Tetraplatia volitans, with its identification based on distribution and basic morphology, was collected as bycatch at roughly $215 \mathrm{~m}$ using a suction sampler attached to the ROV Ventana (Robison 1993) off the coast of California, in the Monterey Bay region on April 2, 2004. Genomic DNA was extracted from the specimen using DNAzol Genomic DNA Isolation Reagent (Molecular Research Center, Inc.) with the following modifications to the manufacturer's protocol. The entire animal was homogenized in $500 \mu \mathrm{l}$ DNAzol reagent and placed in a rotating incubator at room temperature for $48 \mathrm{~h}$. Ten microlitre of $10 \mathrm{mg} \mathrm{ml}^{-1}$ protein kinase were added each $24 \mathrm{~h}$ period, as well as an initial addition of $2 \mu \mathrm{l}$ polyacryl carrier to visualize the DNA. Nearly complete genes 

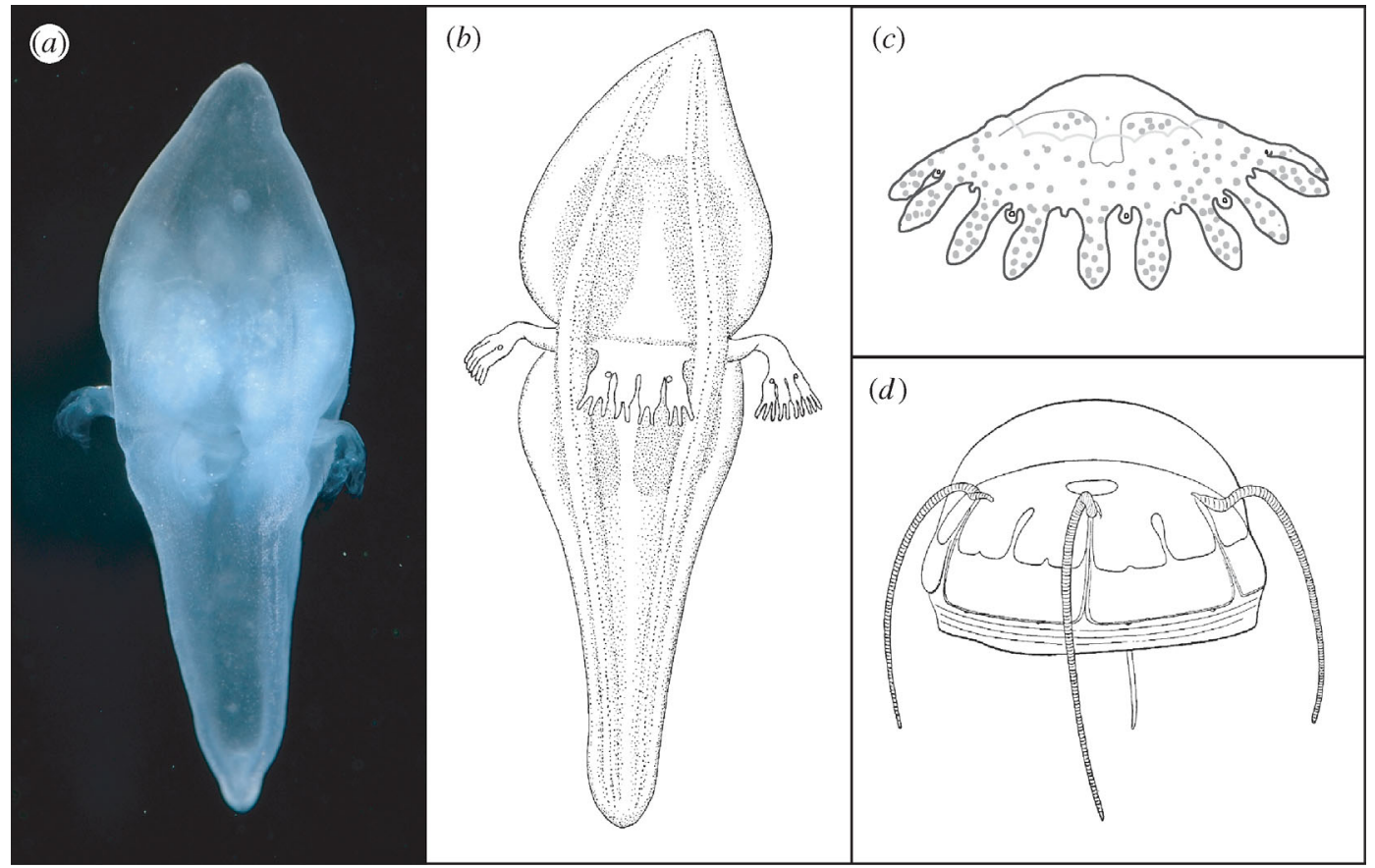

Figure 1. Photo of Tetraplatia volitans, roughly $8 \mathrm{~mm}$ in length (a), diagrammatic sketch of T. volitans (b), and sketches of two cnidarians that have been hypothesized to be close relatives of Tetraplatia, (c) a coronate (Scyphozoa) and (d) a narcomedusan (Hydrozoa). T. volitans (b) drawn by Keiko Hiratsuka Moore; Ephyra of Linuche unguiculata (c) after Mayer (1910); Aegina citrea (d) after Mayer (1910). In all cases, views are perpendicular to the oral-aboral axis and the oral end is directed down.

coding for the small and large subunits of the nuclear ribosome (SSU or $18 \mathrm{~S}$ and LSU or $28 \mathrm{~S}$, respectively) were amplified and sequenced (GenBank Acc. DQ002501-2) as described by Collins et al. (in press). During the review process for this paper, a second sample of $T$. volitans (figure 1) taken off the coast of California yielded an identical SSU sequence.

Sequences were aligned by eye in the SSU and LSU datasets containing numerous other cnidarians (Collins et al., in press). After excluding ambiguous sites, PAUP* 4.0 (Swofford 2002) was used to find best trees using three criteria, maximum likelihood (ML), minimum evolution (ME), and maximum parsimony (MP). Bootstrap analyses were run to assess node support under all three criteria. Model-based analyses (ML and ME) assumed a model of nucleotide evolution obtained using the Akaike Information Criterion, as implemented by MoDelTEst 3.6 (Posada \& Crandall 1998). Our alignments and trees have been submitted to TreeBase (SN2478). In order to determine if our data have sufficient statistical power to falsify hypotheses not found in our optimal topologies, we used the software Consel (Shimodaira \& Hasegawa 2001), run with 10 sets of 100000 bootstrap replicates, to perform approximately unbiased (AU) tests (Kishino \& Hasegawa 1989; Shimodaira 2002). The five hypotheses we tested are: (1) Tetraplatia groups with coronate scyphozoans; (2) Tetraplatia groups with Scyphozoa; (3) Tetraplatia does not group with Hydrozoa; (4) Tetraplatia does not group with Trachylina; and (5) Tetraplatia does not group with Narcomedusae.

\section{RESULTS}

We have rooted the topologies for which LSU and SSU data are most probable (figure 2) with Anthozoa, which is very likely the sister group to Medusozoa (Bridge et al. 1992; and see discussions in Collins 2002 and Marques \& Collins 2004). Both sets of data strongly indicate that $T$. volitans branches within Narcomedusae; bootstrap support for the clade containing $T$. volitans, Aegina citrea, and Solmissus marshalli is 100 irrespective of the optimality criterion used. The SSU dataset contains an additional member of Narcomedusae, Cunina frugifera, and support for the node joining this taxon to the clade containing Tetraplatia is more modest. The AU tests of alternative hypotheses are summarized in table 1 . Both the LSU and SSU data falsify each of the alternatives.

\section{DISCUSSION}

Our data leave little doubt that Tetraplatia is a trachyline medusa that originated within Narcomedusae. This finding accords well with the opinions of a number of past workers (Haeckel 1879; Hand 1955; Leuckart 1866; Viguier 1890; Weill 1934), and contradicts views of Tetraplatia as aberrant cubozoans, scyphozoans, or staurozoans (Delage \& Herouard 1901; Komai 1939; Krohn 1865; Krumbach 1925; Ralph 1960; Russell 1970). More important, however, than who was ultimately correct or incorrect about the phylogenetic affinities of Tetraplatia is coming to a better understanding of the origin and evolution of the morphology of this extraordinary cnidarian.

Those features of Tetraplatia that were generally agreed upon were unpersuasive elements of phylogenetic arguments because of their broad taxonomic distribution. For instance, although the cnidome of Tetraplatia consists solely of atrichous isorhizas and matches that of other Narcomedusae (Weill 1934; Hand 1955), this type of nematocyst is distributed throughout Cnidaria (Schuchert 1993). Similarly, the absence of cells in the mesoglea of Tetraplatia is unconvincing as an argument for hydrozoan affinities because this character state is also shared by cubozoans and staurozoans (see Marques \& Collins 2004 for list of references). Likewise, ecto-endodermal statocysts are present in trachyline medusae (Bouillon \& Boero 2000), cubozoans, and scyphozoans and appear to have been lost in the ancestry of 
(a)

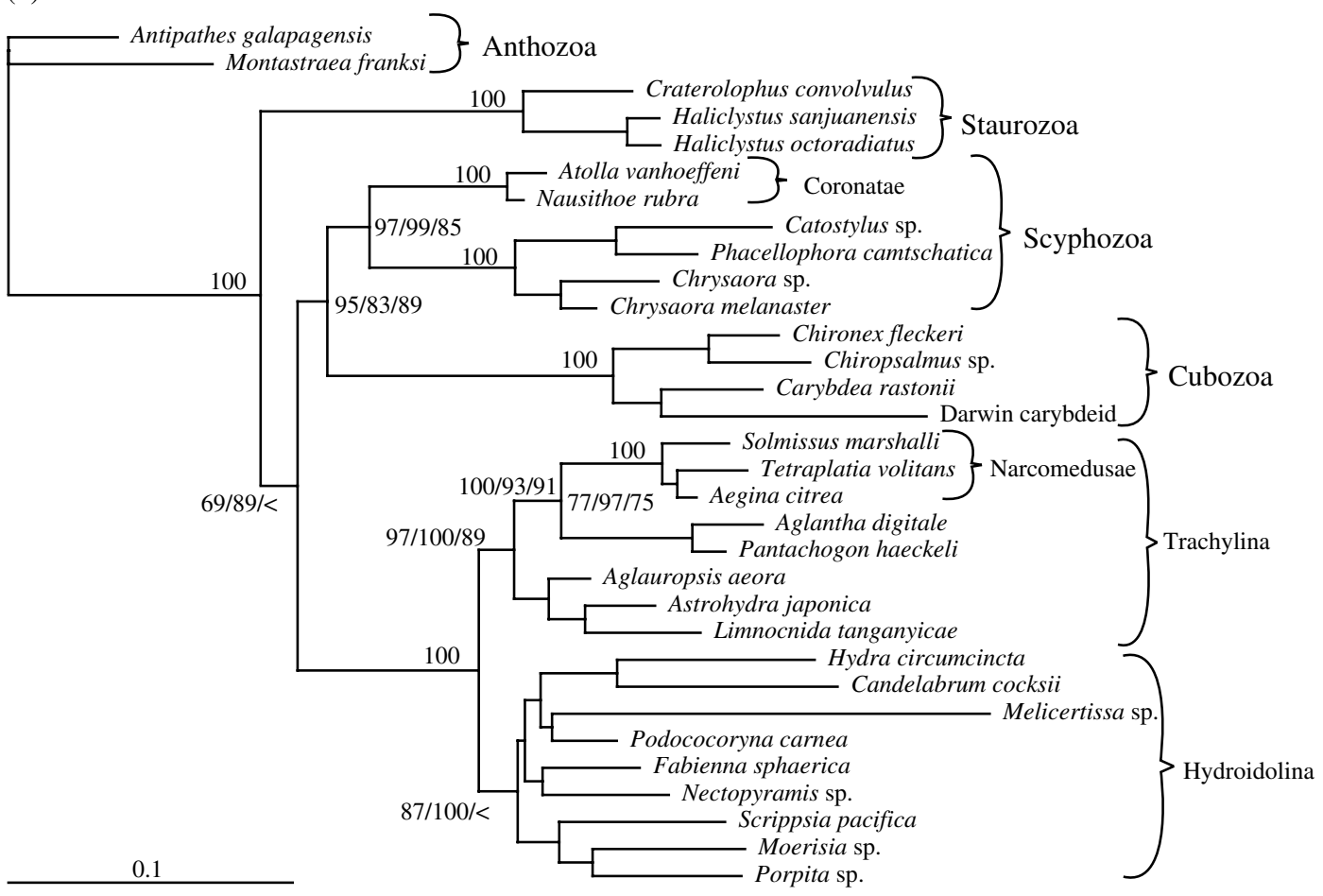

(b)

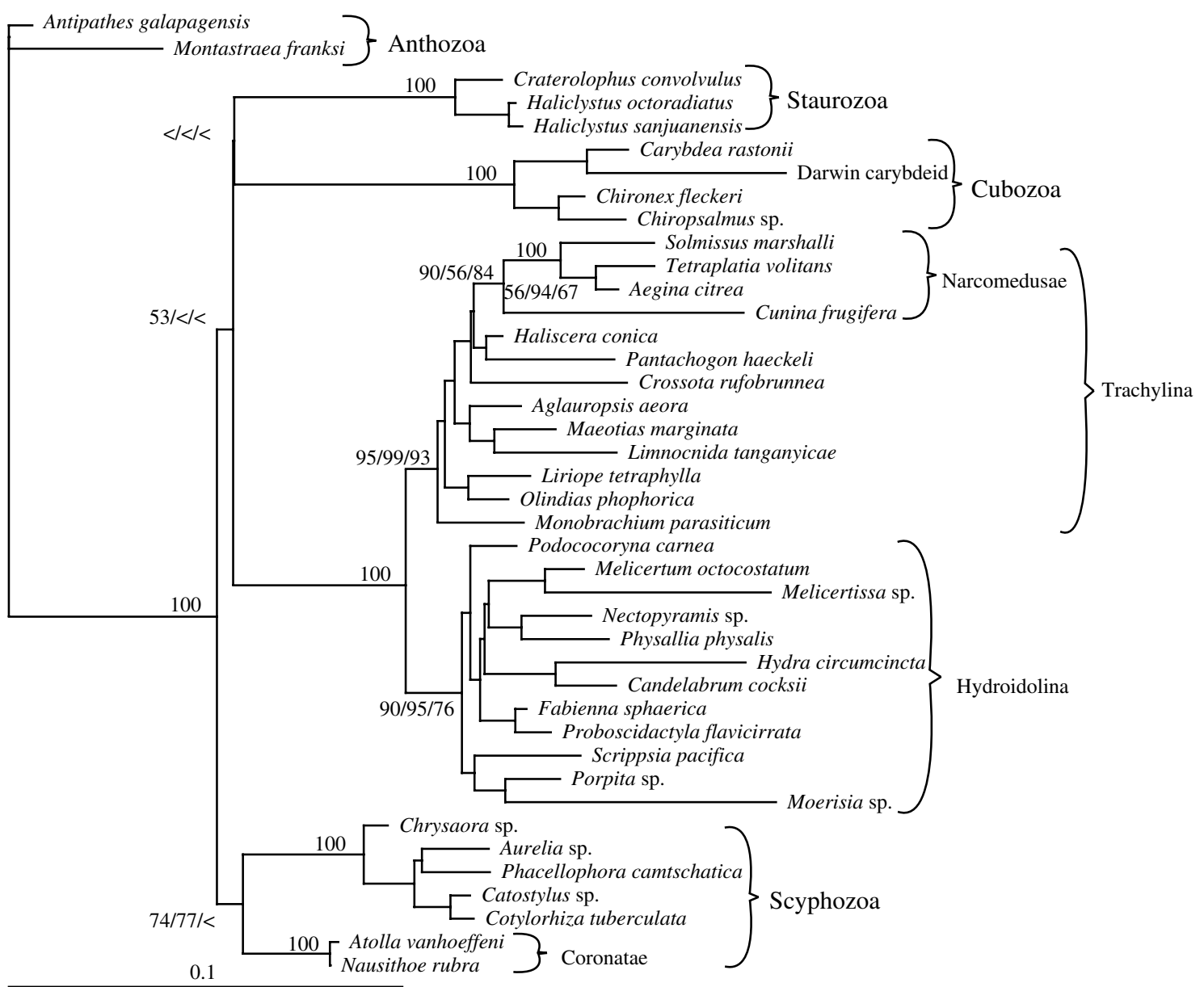

Figure 2. ML topologies based on LSU $(a)$ and SSU $(b)$ data. Bootstrap values under ML, ME, and MP criteria are shown at nodes relevant to the present discussion. Nodes with bootstrap indices of 100 under all three criteria are indicated with a single 100. Bootstrap values less than 50 are represented by $<$. Assumed models of nucleotide evolution for ML and ME tree searches $(G T R+I+G)$ have different rates for each type of substitution, an assumed proportion of invariant sites, and a gamma shape parameter. The length of the bars indicates 0.1 substitutions per site. 
Table 1. Results of approximately unbiased hypothesis tests.

\begin{tabular}{lll}
\hline & \multicolumn{2}{l}{$p$-values } \\
\cline { 2 - 3 } hypothesis & LSU & SSU \\
\hline $\begin{array}{lll}\text { Tetraplatia groups with coronate } \\
\quad \text { scyphozoans }\end{array}$ & $<0.001$ & $<0.001$ \\
$\begin{array}{l}\text { Tetraplatia groups with scyphozoans } \\
\text { Tetraplatia does not group with } \\
\quad \text { Hydrozoa }\end{array}$ & $<0.001$ & $<0.001$ \\
$\begin{array}{l}\text { Tetraplatia does not group with } \\
\quad \text { Trachylina }\end{array}$ & $<0.001$ & $<0.001$ \\
$\begin{array}{l}\text { Tetraplatia does not group with } \\
\text { Narcomedusae }\end{array}$ & 0.035 & $<0.001$ \\
\hline
\end{tabular}

Hydroidolina (Collins et al. in press). More specifically, however, two features associated with the statocysts appear to be autapomorphic for Tetraplatia. First, the statocysts of Tetraplatia are on the oral sides of the swimming flaps, whereas those of other trachylines are located at the umbrellar margin (Bouillon \& Boero 2000). Second, other narcomedusans have statocysts that hang free unlike those of Tetraplatia, which are enclosed.

Ralph (1960) claimed that Tetraplatia has gastric filaments, which would contradict a hydrozoan hypothesis. However, she makes it very clear that she was seeking an explanation for the apparent absence of gastric filaments in what she held to be a scyphozoan, and concluded that the gastric filaments must have the unusual condition of being contained wholly within the gonads. Given the analysis presented here, Tetraplatia either lacks gastric filaments or has independently acquired them. Our new rDNA data are not likely, however, to solve the dispute about whether the gonads of Tetraplatia are of gastrodermal (Komai 1939; Ralph 1960) or epidermal origin (Hand 1955). The gametes of non-hydrozoans originate and remain located in the gastrodermis, whereas those of hydrozoans originate either in the gastrodermis or epidermis, and the vast majority of species store the mature sexual cells in the epidermis. However, in some narcomedusans, the gonads are gastrodermal (Bouillon 1987).

A typical hydrozoan feature is the velum, a circular membrane composed by two epidermal epithelia that project into the subumbrellar space of the medusa. The most distal portions of Tetraplatia's locomotory flaps, which have finger-like projections, are composed of two tissue layers and have been hypothesized to be homologous to the hydrozoan velum when viewed as epidermal (Carlgren 1909; Dantan 1925; Hand 1955). In contrast, Komai (1939) viewed the distal portions of the flaps as gastrodermal and as homologous to the tentacles of other medusae, despite their locomotory function and lack of nematocysts. Ralph (1960), though agreeing with others in interpreting the distal portions of the finger-like processes as being composed of two epidermal layers, viewed each flap as being derived from the fusion of two lappets of scyphozoan ephyrae. Because it is highly unlikely that Tetraplatia is derived from a scyphozoan, the distal portions of the muscular swimming flaps may indeed be vestiges of a velum.

Hand (1955) laid out two possibilities for how such an unusual form as Tetraplatia could have evolved from a trachyline ancestor, either as an early diverging member of the group, in which case its morphology might reflect a pre-medusan stage, or as a recent descendant of the narcomedusan family Aeginidae. Our analyses include only a small number of other narcomedusans, but in each of our datasets, Tetraplatia is identified as a close relative of $A$. citrea, a member of Aeginidae (figure 2). Aeginids are distinguished from other narcomedusans by the presence of interradial manubrial pouches. Tetraplatia also possesses pouches, which run up into the flying buttresses in T. volitans, in the oral portion of its gut, suggesting that this portion of the body may be homologous to the manubrium of other narcomedusans. Placing Tetraplatia within a comprehensive phylogenetic analysis of Narcomedusae should shed light on the origin of its distinctive features. Unfortunately no time-calibrated tree exists for Cnidaria, but its deeply nested position within Narcomedusae suggests that no matter how the morphology of Tetraplatia relates to that of other narcomedusans, its novel medusozoan body plan probably arose in the relatively recent past. This is remarkable because the history of metazoan life suggests that distinct body plans are mostly of ancient origin (Erwin et al. 1987).

We thank Bruce H. Robison and the crew of the RV Point Lobos and ROV Ventana, Lynne Christianson for sequencing $18 \mathrm{~S}$ from the second specimen of $T$. volitans on short order, Jeffrey D. Silberman for the use of his computer cluster for our phylogenetic analyses, Keiko Hiratsuka Moore for drawing Tetraplatia, Vicki Pearse, Peter Schuchert, and Jim Valentine for reading an earlier version of this MS; and two referees who provided helpful comments. We are especially grateful to Cadet Hand for writing such an inspiring and insightful paper on Tetraplatia.

Bouillon, J. 1987 Considérations sur le développement des Narcoméduses et sur leur position phylogénétique. IndoMalayan Zool. 4, 189-278.

Bouillon, J. \& Boero, F. 2000 The Hydrozoa: a new classification in the light of old knowledge. Thalassia Salentina 24, 3-45.

Bridge, D., Cunningham, C. W., Schierwater, B., Desalle, R. \& Buss, L. W. 1992 Class-level relationships in the phylum cnidaria-evidence from mitochondrial genome structure. Proc. Natl Acad. Sci. USA 89, 8750-8753.

Carlgren, O. 1909 Tetraplatien. Tetraplatien. Wiss. Ergebn. Valdivia 19, 75-122.

Claus, C. 1878 Über Tetrapteron (Tetraplatia) volitans. Arch. Mikr. Anat. 15, 349-359.

Collins, A. G. 2002 Phylogeny of Medusozoa and the evolution of cnidarian life cycles. F. Evol. Biol. 15, 418-432. (doi:10.1046/j.1420-9101.2002.00403.x)

Collins, A. G., Schuchert, P., Marques, A. C., Jankowski, T., Medina, M. \& Schierwater, B. In press. Medusozoan phylogeny and character evolution clarified by new large and small subunit rDNA data and an assessment of the utility of phylogenetic mixture models. Syst. Biol.

Dantan, L. 1925 Contribution à l'étude du Tetraplatia volitans. Annal. Inst. Oceanograph. Monaco 2, 429-459.

Delage, Y. \& Herouard, E. 1901 Traité d. Zool., Concr. 2, Les Coelentérés. Paris: Librairie Schleicher Frères Eds. 
Erwin, D. H., Valentine, J. W. \& Sepkoski Jr, J. J. 1987 A comparative study of diversification events: the early Paleozoic versus the Mesozoic. Evolution 41, 1177-1186.

Haeckel, E. 1879 Das system der medusen: erster theil einer monographie der medusen. Jena: G. Fischer.

Hand, C. 1955 A study of the structure, affinities, and distribution of Tetraplatia volitans Busch (Coelenterata: Hydrozoa: Pteromedusae). Pacif. Sci. 9, 332-348.

Kishino, H. \& Hasegawa, M. 1989 Evaluation of the maximum likelihood estimate of the evolutionary tree topologies from DNA sequence data, and the branching order of Hominoidea. F. Mol. Evol. 29, 170-179. (doi:10.1007/BF02100115)

Komai, T. 1939 On the enigmatic coelenterate Tetraplatia. Fap. F. Zool. 8, 231-250.

Krohn, A. 1865 Über Tetraplatia volitans. Arch. Naturg. 31, 337-341.

Krumbach, T. 1925 Scyphozoa. In Handbuch der Zoologie (ed. W. Kükenthal \& T. Krumbach), vol. 1, pp. 522-686. Berlin: de Gruyter.

Leuckart, R. 1866 Bericht über die wissenschaftlichen Leistungen in der Naturgeschichte der niederen Tiere während der Jahre 1864 u 1865. Arch. Naturgesch. 170, 170.

Marques, A. C. \& Collins, A. G. 2004 Cladistic analysis of Medusozoa and cnidarian evolution. Invert. Biol. 123, 23-42.

Mayer, A. G. 1910 Medusae of the World. Washington, D.C.: Carnegie Institution.

Posada, D. \& Crandall, K. A. 1998 MODELTEST: testing the model of DNA substitution. Bioinformatics 14, 817-818. (doi:10.1093/bioinformatics/14.9.817)
Ralph, P. M. 1959 Notes on the species of the pteromedusan genus Tetraplatia. f. Mar. Biol. Assn. UK 38, 369-379.

Ralph, P. M. 1960 Tetraplatia, a coronate scyphomedusan. Proc. R. Soc. B 152, 263-281.

Rees, W. J. \& White, E. 1957 Two new records of Tetraplatia chuni Carlgren from the South Atlantic. F. Faculty Sci. Hokkaido Univ. (Ser. 6: Zool.) 13, 101-104.

Robison, B. H. 1993 Midwater research methods with MBARI's ROV. Mar. Tech. Soc. F. 26, 32-39.

Russell, F. S. 1970 Medusae of the British Isles. II. Pelagic Scyphozoa with a supplement to the first volume on hydromedusae. Cambridge, MA: Cambridge University Press.

Schuchert, P. 1993 Phylogenetic analysis of the Cnidaria. Zeits. Zool. Syst. Evol. 31, 161-173.

Shimodaira, H. 2002 An approximately unbiased test of phylogenetic tree selection. Syst. Biol. 51, 492-508. (doi:10.1080/10635150290069913)

Shimodaira, H. \& Hasegawa, M. 2001 CONSEL: for assessing the confidence of phylogenetic tree selection. Bioinformatics 17, 1246-1247. (doi:10.1093/bioinformatics/17.12.1246)

Swofford, D. L. 2002 PAUP*: 4.0 Phylogenetic analysis using parsimony (*and other methods), v. 4. Sunderland, MA: Sinauer Associates.

Viguier, C. 1890 Études sur les animaux inférieurs de la Baie d'Algier IV. le Tétraptère (Tetraplatia volitans, Busch). Arch. d. Zool. Exp. Gen. Paris, Ser. 2 8, 101-142.

Weill, R. 1934 Contribution à l'étude des cnidaires et de leurs nématocystes. 1. Recherches sur les nématocystes (Morphologie, Physiologie, Développement). 2. Valeur taxonomique du cnidome. Trav. Sta. Zool. Wimereux 11, $1-701$. 